Proceedings

\title{
Water Hygiene Audit and Legionella Control in Hospitals ${ }^{+}$
}

\author{
Daniela Kaposztasova * and Zuzana Vranayova \\ Institute of Architectural Engineering, Department of Building Services, Faculty of Civil Engineering, \\ Technical University of Kosice, 04200 Kosice, Slovakia; zuzana.vranayova@tuke.sk \\ * Correspondence: daniela.kaposztasova@tuke.sk; Tel.: +421-55-602-4143 \\ + Presented at the 3rd EWaS International Conference on "Insights on the Water-Energy-Food Nexus", \\ Lefkada Island, Greece, 27-30 June 2018.
}

Published: 31 July 2018

\begin{abstract}
The multidisciplinary Legionella research has developed hand in hand with the level of science and technology, health care, and other scientific fields. The primary aim of this paper is to present our research focused on the theoretical and experimental analysis of building water distribution systems from the point of view of microbiological risk in hospitals in the Slovak Republic. To assess the potential public health impact of Legionella colonization in hot and cold water, a study was undertaken to identify and qualify the levels of the microorganism. The measures proved that thermal disinfection is not a systematic solution. By applying preventive measures, physical or chemical treatment and the use of risk management, we can obtain a secure system which eliminates costly solutions. The outputs of our goals will be transformed to the hygienic water audit scheme as a tool in the fight against Legionella contamination in the future.
\end{abstract}

Keywords: hot water; Legionella pneumophila; thermal disinfection; temperature; water samples; hospital

\section{Introduction}

Monitoring and control technologies are inevitable for the production of safe drinking water [1].Outbreaks of the illness occur from exposure to Legionella growing in purpose-built systems where water is maintained at a temperature high enough to encourage growth, e.g., cooling towers, evaporative condensers, hot and cold water systems, and spa pools used in all sorts of premises (work and domestic) [2]. Forty-six Legionella infections have been diagnosed inpatients of a hospital in the Lisbon area of Portugal since 31 October 2017, where four of the patients died. Portuguese health officials suspect the source of the outbreak was the hospital's potable plumbing system [3]. This is just an example of a number of recent outbreaks not only in hospitals caused by this ubiquitous bacteria (more cases in [3]). Although both forms of legionellosis may occur epidemically, only Legionnaire Disease (LD) is subject to mandatory reporting within Slovakia and international reporting to the European Center for Disease Control (ECDC) via the ELDSNet network to TESSy and through the network for so-travel infections. There are at least 5000 to 6000 people in Europe every year and, despite well-known treatments, intensive surveillance, and disease studies and factors affecting the incidence of LDs, annually, approximately 450 people die. Between 2011 and 2015, 29 countries reported a total of 30,532 diseases, 2.6 times more in males than in females, with $70 \%$ of the infections being community-based, $20 \%$ of them travel-related, and $10 \%$ of those in health care facilities [4]. In Slovakia, the incidence of LD is low, from 1985 to 2015, the infection was diagnosed in 117 patients, 71 men and 46 women. The low number of reported LD cases can also be related to the fact that the legionella diagnosis is not routinely performed in 
Slovakia, but only at a single site at the Institute of Epidemiology at the Faculty of Medicine, Charles University in Bratislava [5]. Healthcare facilities represent an at-risk environment for legionellosis transmission occurring after the inhalation of contaminated aerosols [6-10] by patients. The most appropriate method for controlling the risk from Legionella is to control its presence in the water, eliminating the key risk factors and limiting the numbers capable of being disseminated $[10,11]$.Worldwide, there have been numerous studies which have linked water distribution systems as the source of legionella contamination and was deeply described by Whiley in [12].

\section{The Occurrence of Legionella Bacteria and Its Effects on Humans in Slovakia}

In the context of hot water preparation, it is necessary to remember the possibility of health risks caused by legionella. Legionellosis is a non-poisonous disease caused by Legionella bacteria, most often caused by the inhalation of contaminated aerosol. Incubation times vary from 2 to 14 days, rarely longer. The disease is similar to Pontiac fever, or it may have a more serious form, Legionnaire Disease (LD), which can lead to sepsis without causative treatment, and $40 \%$ of nosocomial legionella cases can lead to fatal death for patients with increased risk. Between October and December 2016, 26 people from seven EU countries suffered LD during their stay in Dubai. In 2016, legionellosis in Slovakia of 14 patients was diagnosed, of which two diseases were imported during stays in the Czech Republic and Italy. A total of 756 samples from the environment were examined for the presence of legionella. Most positive findings were, as in previous years, in hot water $(45.2 \%)$. Drinking water made up $16 \%$ of the positive samples. Epidemiologically most important Legionella pneumophila spp. 1, responsible for the most serious infections, was present in $38.46 \%$ of the samples from the total number of positive water samples [13].

Legionella bacteria naturally occur in surface waters, but their concentration is negligible. Conditions for the multiplication of these bacteria are around temperatures of 35 to $42{ }^{\circ} \mathrm{C}$, where under favorable conditions, they can reach 106 bacteria per liter of water. In the temperature range of $45^{\circ} \mathrm{C}$ to $55^{\circ} \mathrm{C}$, the bacterial growth process is already stopped. e.g., at a water temperature of 50 ${ }^{\circ} \mathrm{C}$, the reduction time of the bacterium is 80 to $11 \mathrm{~min}$, at $55^{\circ} \mathrm{C}$ it is $19 \mathrm{~min}$. Only between $60{ }^{\circ} \mathrm{C}$ and $65^{\circ} \mathrm{C}$ bacteria are eliminated within a few minutes (at a water temperature of $60^{\circ} \mathrm{C}$ for $2 \mathrm{~min}$ ) and at $70^{\circ} \mathrm{C}$ and more, it is already seconds $[3,9,10]$. From the above, it follows that the ideal place for their multiplication are hot water systems where both temperature and other conditions (hot water piping parts with stagnation, sludge, increased iron concentration, etc.) can be ideal.

\section{Materials and Methods}

The main aim is to reduce the risk of Legionella and other pathogens and show the necessity of prevention and regulations for installations in hospitals by exploring the system solutions.

Three specific aims were addressed:

1. To estimate the frequency of Legionella colonization and severity of contamination at different levels in hospitals/health care facilities in Eastern Slovakia.

2. To define the relative role of each risk factor (temperature, material base, etc.) and suggest possible remediation.

3. To identify the potential risk factors for contamination relative to distribution systems and water characteristics (critical control points, risk analysis proposal of so called Hygienic Water Audit Scheme) [14].

Finally, the risk for legionellosis will be retrospectively evaluated by collecting information about pneumonia symptoms recorded by residents at buildings and hospitals. To achieve these aims, we need to start with the characteristics of hot water and a comparison of the most used methods for legionella reduction as chemical treatment versus physical treatment. The main aim of this paper is to present the results of the frequency of Legionella colonization and severity of contamination at different levels in hospitals/health care facilities in Eastern Slovakia. 


\subsection{Hot Water Characteristics}

Heated cold water-hot water is water that reaches the quality parameters set for drinking water for human consumption. It is not intended for drinking and cooking, but for washing, bathing, cleaning, etc. It is not a heated service water for technological use. If we want to use water that does not reach the drinking water quality parameters (for toilets, cleaning floors, windows... etc.) in the building, a separated water system design is inevitable and this water supply must be secured so that water cannot be mixed with the water supply for human consumption. Outlets from both internal water mains must be clearly and permanently marked [15].

The quality of hot water is strictly controlled. It must comply with the bacteriological, biological, and chemical criteria given by the Decree of the Ministry of Agriculture of the Czech Republic No. 252/2004 Coll. and No. 247/2017 Coll. in the Slovak Republic. It sets the hygiene requirements for potable and hot water, the frequency and extent of the control of drinking and hot water.

As the temperature rises, the chemical reactivity of the water increases, which occurs in the metal parts of the corrosion duct and in the water heating and plastic piping system due to the incrustation, the overgrowth of the pipeline.

The main indicators of heated potable water include [15]:

- $\quad \mathrm{KNK} 4.5-\mathrm{min} 0.8 \mathrm{mmol} / \mathrm{L}$ (acid neutralization capacity - water alkalinity - the property of water that informs about the ability to bind hydroxide or hydrogen ions),

- mass concentration of phosphates (max. $3.5 \mathrm{mg} / \mathrm{L} \mathrm{PO}$ ) in hot water,

- $\mathrm{pH}$ value at $20^{\circ} \mathrm{C}$ in the range of 6.5 to 9.5 (upper limit),

- concentrations of chloride not more than $100 \mathrm{mg} / \mathrm{L}$,

- manganic mass concentration not more than $0.05 \mathrm{mg} / \mathrm{L}$,

- iron concentration of $0.20 \mathrm{mg} / \mathrm{L}$,

- concentration of calcium and magnesium of 2-3.5 mmol/L is in terms of drinking water quality, at higher values, water treatment for heating (softener installation, magnetization, etc.)

- mass concentration of $\mathrm{CO}_{2}$.

These parameters are perfectly suitable for water heating. If not, cold water treatment is required before the heating process.

\subsection{Methods of Legionella Elimination in Hot Water Distribution Systems}

To control Legionella colonization in hot water distribution systems, first, knowledge of the whole technical water service system - operation of the pipeline network should be provided by the designers, but also by installers and operators directly related to the results of microbiological examination and comparison with other parameters of hot water.

It is important to make better use of the measurement and regulation system with the management of the domestic hot water system including hot water preparation-knowledge of hot water consumption-separate water meter for cold water supply for heating, water temperature measurement in individual circulating branches, connection to the satisfaction of supply of hot water from the user point of view - temperature at the distribution points of the consumer etc...

It is therefore, in principle, prevention, technical, and organizational measures in this regard. If everything is "okay" in technical and technological terms, and still microbial colonization takes place, it is an indicator of the unsatisfactory quality of the water supplied and technical measures are necessary.

The basic technical measures for the elimination of Legionella bacteria include:

- physical treatment such as thermal disinfection (with proof of the realized temperature at the distribution points), use of UV emitters, use of ionization using Ag-Cu electrodes-physicochemical technology.

- chemical treatment including the use of bioconics based on hypochlorite solution supplied by the manufacturer, use of chlorine-containing anolyte (produced by electrolysis of $\mathrm{NaCl}$ on site), 
use of biocides based on other halogens, use of chlorine dioxide (chlorine dioxide) produced at the site of dosing ("in situ") from the production of compounds without a generator, use of chlorine dioxide in the form of a stabilized solution supplied by the manufacturer, use of chlorine dioxide produced in situ ("in situ") from chemicals by a generator, use of hydrogen peroxide with silver, use of peracetic acid (PERSTERIL), use of non-oxidizing biocides... etc. [10].

For hygiene safety, there are more options and different requirements to fight against Legionella. While for hospitals with immunosuppressed patients (e.g., ARO, transplantation clinics) the value of the legionella bacteria is to be permanently at zero, for other accommodation facilities, according to the Decree of the Ministry of Agriculture of the Czech Republic No. 252/2004 Coll., Annex 2, "Recommended value $100 \mathrm{KTJ}$ per $100 \mathrm{~mL}$ ". In the Slovak Republic it is permanently on zero level in all cases $[10,15]$.

\section{Results}

\subsection{Hygienic Water Audit Scheme}

Water audits these days are as important as energy audits. The main aim is to determine the amount of water lost from the distribution system due to leakage and of course, the costs of such losses $[16,17]$. The overall report of water management in building is prepared as a detailed profile of the distribution system and water users, thereby facilitating an easier and effective management of the resources with improved reliability. It helps to identify the problem parts and face them in order to suggest optimum solutions. As is described in $[16,17]$ and many other studies, it is a very good tool for real understanding and assessment of the present performance level and efficiency of the service and the adaptability of the system for future expansion and rectification of faults during modernization $[16,17]$. A very important part of the water audit is the hygienic safety of hot and cold water as it is also described in water safety plans-WSP [18]. Not only are losses of water important, but also the quality that is delivered to the customer. Now, we are working on the water hygienic scheme (Figure 1).

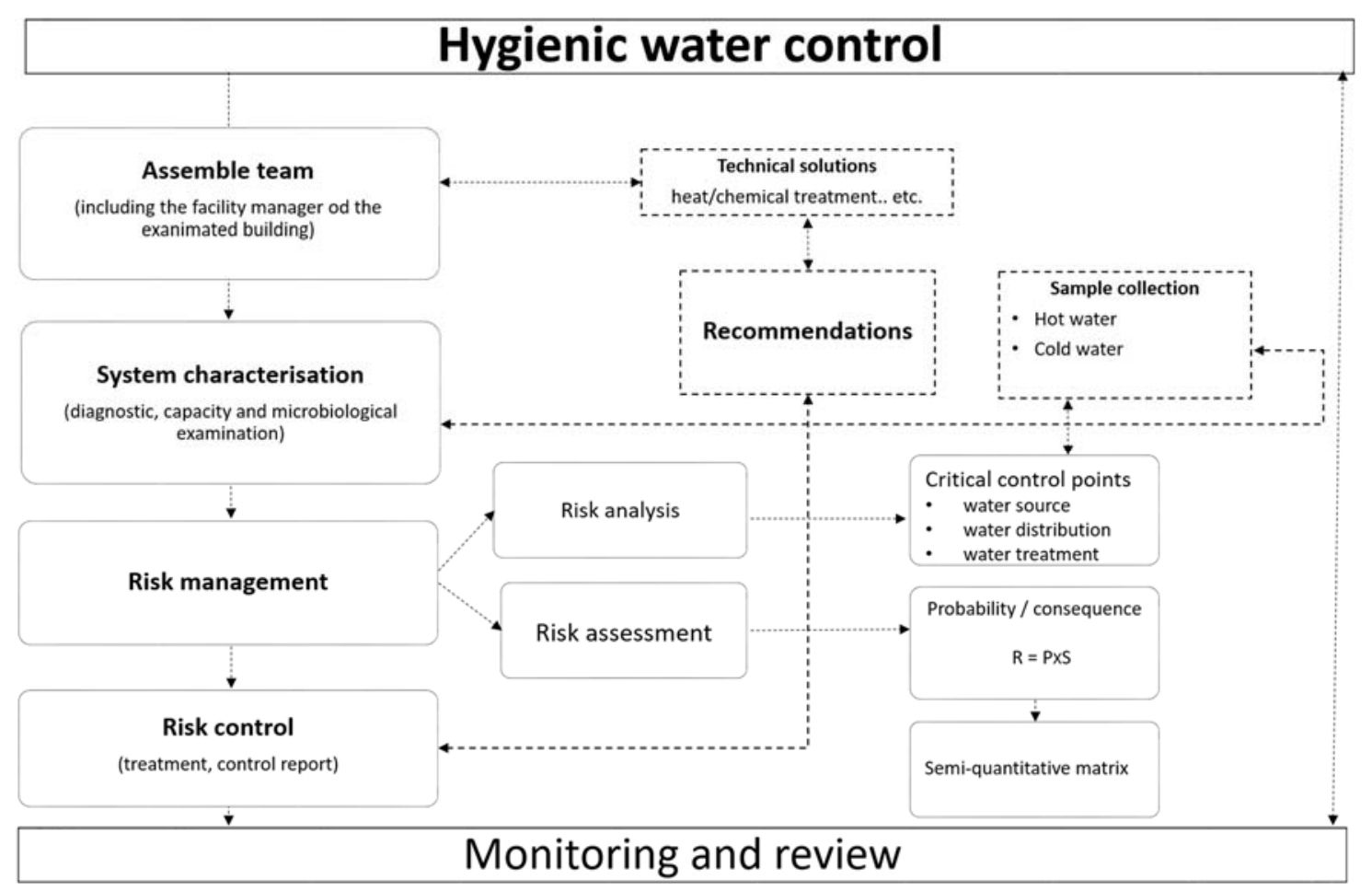

Figure 1. Flow diagram of water control program. 
By using the risk management approaches, assembling the team, monitoring the systems, identifying the risks, measuring and sample collection, we would like to find the most appropriate solution that will be targeted on the examined building (in our case hospitals and health care facilities).

\subsection{Risk Analysis and Risk Assessment}

Risk analysis was one of the methodological procedures in phase 1 to identify possible contamination threats by Legionella pneumophila in water distribution systems. It is an analysis of problems based on the latest scientific and technical knowledge to make the basis and inferences for effective decisions. The goal was to estimate necessary precautionary measures since specific risk assessment is essential for their successful implementation. Risk analysis evaluated specific conditions on the ground of information about current contamination that comprises the assessment of possible ways of proliferation, exposure risk, and the target group risk in each situation. Risk analysis involves risk assessment and risk management. Building owners, landlords, and managers are responsible for assessing sources of risk in the water distribution systems. Risk analysis included four parts: system assessment-identification of risk sources and groups, risk assessment, risk management, and conclusions of risk analysis. As a part of the risk assessment, it is significant to determine the level of risk from the exposure to Legionella bacteria. It is a tool for choosing the proper preventive measures in order to reduce the risk to an acceptable level [19].One result of risk management is a document that ensures the safe and correct operation of hot water at the end of distribution systems for users. The interesting and very important part in risk assessment is the identification of critical control points of the system. Conclusions of risk analysis involve a summary of the risk assessment together with risk management as well as a scheme of precautionary measures to reduce risk and to offer the best solution.

\subsection{Thermal Disinfection vs. Chemical Disinfection}

A range of physical and chemical disinfection methods have been proposed, but up until now, the most effective procedures for controlling contamination have not been defined [20,21]. As was described before, in order to eliminate legionella bacteria, thermal disinfection (heat treatment or heat shock) of hot water is usually recommended. The principle is to heat the water in the whole distribution system at regular intervals to each of the distribution point (end use) discharged through the water at $70{ }^{\circ} \mathrm{C}$ for at least five minutes. Just heating at the water tank (boiler) alone is not sufficient as the bacteria are "distributed" in the piping network and consumers' tap. Chemical disinfection, on the other hand, consists of dispensing the chemical into the hot water systems it comes into all places including the end-of-water batteries where water is discharged. In general, heat disinfection is about $60 \%$ more energy consuming than hot water preparation (based on $1 \mathrm{~m}^{3}$ ). Furthermore, it is also necessary to consider the possible impacts on the lifetime of water distribution (e.g., pipe expansion). In practice, it is stated that using heat disinfection three times results in a shortening of the pipeline life by about $1 \%$ (which is actually $1 \%$ of the costs of the reconstruction of the pipelines).

In the case of chemical disinfection, it can be implemented in any system of preparation and distribution of hot water. When comparing thermal disinfection with chemical, the benefits of reducing the cost of chemical disinfection are clearly shown, while the use of thermal disinfection results in increased costs in many directions. Chemical disinfection allows for the selection of a range of biocides according to purpose, type of piping, and set requirements. The disadvantage is the possible problem of choosing the so- "cheap" chemical disinfection without coordination with the overall operation of the building, without consideration of the state of the distribution network, knowledge of the chemical quality of the supplied cold drinking water, and the disrespect of the fiber composition of the water supply. 


\section{Discussion and Limitations}

During the six years (1995-2001), a study of Legionella identification in three hospitals in the capital city of Slovakia was undertaken by Assoc. Prof. Spalekova [22]. A total of 579 water samples were collected and 173 spp. of legionella isolated. In 2015, we started to collect water samples in the eastern part of Slovakia in Kosice. The main goal was to find out the level of Legionella contamination in selected health facilities. The selection was directly targeted at risky departments in hospitals (geriatrics, gynecology clinic, clinic of pneumoniae, etc.) where the factors that encourage bacteria growth can occur and be dangerous to patients with weakened immunity.

A total of 20 water samples of potable water hot-PWH were collected in four health facilities (five water samples per clinic) as described in the Table 1 [14]. According to STN ISO 11731-part 2 [23] for Legionella presence, all water samples were analyzed. Hospital 1, 2, and 4 were in all cases negative. In hospital 3, all five samples were positive. Results are presented in Table 2.Then, we continued with sample collection in other hospitals. In the case of positive findings, we planned to apply the hygienic water audit scheme to prove it in practice.

Table 1. Water samples of potable hot water in selected hospitals.

\begin{tabular}{|c|c|c|c|}
\hline & Water Samples & Department & Source \\
\hline \multirow{5}{*}{ Hospital 1} & 1 & Department of long-term illness & Shower-for immobile patient \\
\hline & 2 & Department of Internal Medicine & shower \\
\hline & 3 & Department of Gynecology & shower \\
\hline & 4 & Department of Gynecology & shower \\
\hline & 5 & Centre for Burn Injuries & shower \\
\hline \multirow{5}{*}{ Hospital 2} & 1 & Department of Gynecology & shower \\
\hline & 2 & Department of Neurology & shared shower \\
\hline & 3 & Clinic of Infectious Diseases & shower \\
\hline & 4 & Clinic of Pneumonia & shower \\
\hline & 5 & Department of Internal Medicine & shower \\
\hline \multirow{5}{*}{ Hospital 3} & 1 & Department of Gynecology & shower \\
\hline & 2 & Department of Hematology & shower \\
\hline & 3 & Department of Balneology etc. & shared shower \\
\hline & 4 & Department of Psychiatry & shower \\
\hline & 5 & Department of Internal Medicine & shared shower \\
\hline \multirow{5}{*}{ Hospital 4} & 1 & Geriatrics and Gerontology & shower \\
\hline & 2 & Geriatrics and Gerontology & Shower-for immobile patient \\
\hline & 3 & Department of Long-term illness & shared shower \\
\hline & 4 & Department of Long-term illness & shower \\
\hline & 5 & Institute of Preventive Medicine & shower-after ergometry \\
\hline
\end{tabular}

Table 2. Positive findings.

\begin{tabular}{ccllcc}
\hline & \multicolumn{2}{c}{ Positives Samples } & \multicolumn{2}{c}{ Legionella Species } \\
\hline & Water Samples & \multicolumn{1}{c}{ Department } & Source & CFU/100 mL & Serotype \\
\hline \multirow{4}{*}{ Hospital 3 } & 1 & Department of Gynecology & shower & 3400 & 3 \\
& 2 & Department of Hematology & shower & 1200 & 1 \\
& 3 & Department of Balneology etc. & shared shower & 1600 & 3 \\
& 4 & Department of Psychiatry & shower & 4600 & 3 \\
\hline
\end{tabular}

According to the prevention and control of operational conditions, we applied the recommendations to hospital 3 with the detected legionella species. Prevention is the most important part of water distribution management. Following the type of material that is used for the pipelines and whole distribution, not only in terms of lifespan, appropriate hydraulic design, measurement and regulation, the quality of potable cold water used for hot water heating means that testing is required to ensure the following: 
- quality of incoming cold water for heating according the set requirements (possible chemical or physical treatment);

- elimination of materials which promote the formation of biofilm on the inner surface of the pipe-the seal, corner valves with a filter etc.;

- installation of sampling valves for hot water and circulating near heating;

- implementation of the initial disinfection of the internal water supply system, control of boilers...systems for water heating;

- elimination of stagnation of water in the pipeline of the internal water main (during construction works pipelines are impregnated, but without collection, holiday time;

- hydraulic regulation (flows, pressures, circulation);

- capacity testing (control of heat stability in the system from recorded temperature of hot water in risers or outer distribution point);

- regular elimination of sludge from the system-drainage of storage tanks or heaters, filters, tangential dirt separators and horizontal-backbone piping sections, check of expansion vessel status (where there may be water stagnation);

- regular cleaning of storage tanks and heaters-monitoring;

- hygienic security solution-the microbiological status of the hot water produced in the given installation and the distribution points of the internal water supply.

\section{Conclusions}

In conclusion, our work was the study of evaluating the presence of Legionella and the potable water quality. Potable hot and cold water quality must by ensured by using a regular monitoring scheme such as the hygienic water audit to ensure public health safety. Impaired disinfection is not able to reliably meet current requirements, so strategies are being tilted towards permanent disinfection. It is also important to focus on other ways of protecting water. The advantage of using ozone or chlorine dioxide is the high microbiological efficiency at low concentrations without affecting the sensory properties of water. Even in their longer term use, bacteria cannot be adapted and decontamination of the distribution system is possible without interruption of operation. The advantage of these systems is also the long service life and low maintenance costs. Due to the lack of overheating in thermal disinfection and near zero water flow, the riskiest place is clearly the lower part of the hot water tanks - the casting throat. Here, the conditions for the growth of Legionella bacteria are maintained and, in the event of a drop in temperature in the reservoir, they can colonize the whole system. We started the long-term monitoring for legionella elimination by chemical disinfection in Slovak and Czech hospitals. The hygienic water audit should help the hospitals to control the legionella risk and set the best solution for their case.

Acknowledgments: This work was supported by the Slovak Research and Development Agency under the contract No. VEGA 1/0697/17 Hygienic water audit platform as transition tool to Legionella free water and HVAC systems in hospitals.

\section{References}

1. Ocipová, D.; Vranayova, Z.; Sikula, O. Negative impact of bacteria Legionella pneumophila in hot water distribution systems on human health. World Acad. Sci. Eng. Technol. 2012, 6, 670-674.

2. Health and Safety Executive. Available online: http://www.hse.gov.uk/legionnaires/what-is.htm (accessed on 20 January 2018).

3. HC Info. Available online: https://hcinfo.com/about/outbreaks/ (accessed on 18 December 2017).

4. Beauté, J. Surveillance and outbreak reports. In Legionnaires'disease in Europe, 2011-2015; European Centre for Disease Prevention and Control, European Centre for Disease Prevention and Control (ECDC): Stockholm, Sweden, 2016.

5. Spaleková, M.; Kotrbancová, M. The Issue of Comprehensive Diagnosis of Legionellosis/Problematika Komplexnej Diagnostiky Legionelóz. In Proceedings of the XI International conference NRC, Bratislava, Slovakia, 18 March 2014. 
6. Montagna, M.T.; De Giglio, O.; Cristina, M.L.; Napoli, C.; Pacifico, C.; Agodi, A.; Baldovin, T.; Casini, B.; Coniglio, M.A.; D'Errico, M.M.; et al. Evaluation of Legionella air contamination in healthcare facilities by different sampling methods: An Italian multicenter study. Int. J. Environ. Res. Public Health 2017, 14, 670, doi:10.3390/ijerph14070670.

7. Zuravleff, J.J.; Yu, V.L.; Shonnard, J.W.; Rihs, J.D.; Best, M. Legionella pneumophila contamination of a hospital humidifier: demonstration of aerosol transmission and subsequent subclinical infection in exposed guinea pigs. Am. Rev. Respir. Dis. 1983, 128, 657-661.

8. Roig, J.; Aguilar, X.; Ruiz, J.; Domingo, C.; Mesalles, E.; Manterola, J.; Morera, J. Comparative study of Legionella pneumophila and other nosocomial pneumonias. Chest 1991, 99, 344-350.

9. Marchesi, I.; Marchegiano, P.; Bargellini, A.; Cencetti, S.; Frezza, G.; Miselli, M.; Borella, P. Effectiveness of different methods to control legionella in the water supply: Ten-year experience in an Italian university hospital. J. Hosp. Infect. 2011, 77, 47-51.

10. Bartram, J.; Chartier, Y.; Lee, J.V.; Pond, K.; Surman-Lee, S. Legionella and the Prevention of Legionellosis; World Health Organization: Geneva, Switzerland, 2007.

11. Collins, S.; Walker, J. Comment on Montagna, et al. Evaluation of Legionella air contamination in healthcare facilities by different sampling methods: An Italian multicenter study. Int. J. Environ. Res. Public Health 2017, 14, 670. Int. J. Environ. Res. Public Health 2017, 14, 876, doi:10.3390/ijerph14080876

12. Whiley, H. Legionella Risk Management and Control in Potable Water Systems: Argument for the Abolishment of Routine Testing. Int. J. Environ. Res. Public Health 2017, 14, 12, doi:10.3390/ijerph14010012.

13. Ministry of Agriculture and Rural Development of the Slovak Republic. Report on Zoonózy. Správa o Zoonózach, Alimentárnych Nákazách a Nákazách z Vody v Slovenskej Republike Za Rok 2016. Available online: http://www.mpsr.sk/index.php?navID=506\&navID2=506\&sID=111\&id=11997 (accessed on accessed on 18 December 2017).

14. Vranyova, Z.; Kaposztasova, D. System Solutions in the Fight against Infection Caused by Bacteria Legionella, Water Supply and Drainage in Buildings, CIB Conference; TVVL: Amsterdam, The Netherlands, 2017; pp. 485-494.

15. Jirout, V. Př́iprava Teplé Vody. Sešit Projektanta č. 3. Druhé Přepracované Vydání; STP-OS02-Heating/Vytápění; STP: Praha, Czech, 2007; ISBN 978-80-02-01910-7.

16. Water Audit Report; Rowley Water Department: Rowley, MA, USA, June 2016. Available online: http://www.rowleywater.com/file/water\%20audit\%202016.pdf (accessed on 12 December 2017).

17. General Guidelines for Water Audit and Water Conservation. Available online: http://www.cwc.gov.in/main/downloads/Water\%20Audit\%20\&\%20Water\%20Conservation\%20Final.pdf (accessed on 6 January 2018).

18. WSP Manual. Available online: http://www.who.int/water_sanitation_health/publications/publication _9789241562638/en/ (accessed on 2 January 2018).

19. Ocipova, D. Hot water system contamination in the frame of central heat supply. In Budownictwo o Zoptimalizowanym Potencjale Energeticznym; Wydawnictva Politechniki Czestochowskiej: Czestochowa, Poland, 2007; pp. 406-411, ISBN 978-83-7193-357-8.

20. Marchesi, I.; Ferranti, G.; Mansi, A.; Marcelloni, A.M.; Proietto, A.R.; Saini, N.; Borella, P.; Bargellini, A. Control of Legionella Contamination and Risk of Corrosion in Hospital Water Networks following Various Disinfection Procedures. Appl. Environ. Microbiol. 2016, 82, 2959-2965, doi:10.1128/AEM.03873-15.

21. Lin, Y.E.; Stout, J.E.; Yu, V.L. Controlling Legionella in hospital drinking water: An evidence-based review of disinfection methods. Infect. Control Hosp. Epidemiol. 2011, 32, 166-173, doi:10.1086/657934.

22. Lefa.sk. Available online: http://www.lefa.sk/internet/nozokom/2003/2003-2/03.pdf (accessed on 3 November 2017).

23. STN ISO 11731. Water Quality-Detection and Enumeration of Legionella-Part 2: Direct Membrane Filtration Method for Waters with Low Bacterial Counts; ISO 11731-2:2004; International Organization for Standardization: Geneva, Switzerland, 2004.

(C) 2018 by the authors. Licensee MDPI, Basel, Switzerland. This article is an open access article distributed under the terms and conditions of the Creative Commons Attribution (CC BY) license (http://creativecommons.org/licenses/by/4.0/). 